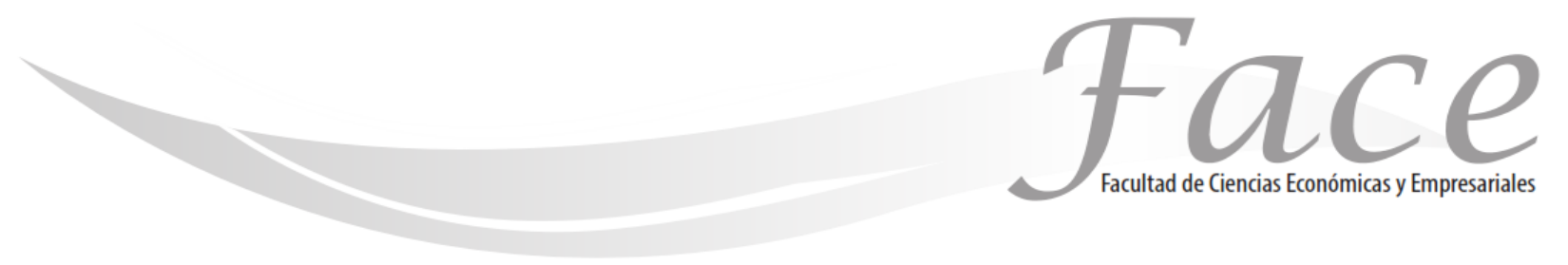

ISSN Impreso: 1794-9920

ISSN Electrónico: 2500-9338

Volumen $16-\mathrm{N}^{\circ} 1$

Año 2016

Págs. 93 - 102

\title{
ANALYSIS OF KEY FACTORS FOR COMPETITIVENESS IN THE SOFTWARE INDUSTRY: PERSPECTIVE OF THE BUSINESSMAN IN COLOMBIA*
}

\author{
Nelson Antonio Moreno Monsalve * \\ Enlace ORCID: http://orcid.org/0000-0002-6372-0430 \\ H. Mauricio Díez Silva* \\ Enlace ORCID: http://orcid.org/0000-0003-1434-9329
}

Fecha de Recepción: 2 de Abril 2016

Fecha de Aprobación: 30 de Junio 2016

\begin{abstract}
:
This paper presents an analysis of the key factors that, seen from the point of view of entrepreneurs in the software development industry in Colombia, may have a positive effect on the competitiveness of this sector. The starting point of this research is based on improvement opportunities for these companies, taking into account the attractive aspect of this industry due to its high degree of innovation and value-added products.

The research was developed with a mixed approach, with an exploratory and a descriptive scope; performing an interpretative work on bibliographic sources and subsequently designing an instrument for acquiring data related to factors that influence the competitiveness of the sector. From these results, a correlation analysis of variables, useful for purposes of sectoral intervention was performed.
\end{abstract}

As a result, there is a correlation between competitiveness and the variables associated with government support, quality of education, existing certifications and processes of economic openness. These results are expected to be useful in promoting programs, plans, and sectoral projects for continuous improvement of the companies that are part of the analyzed sector.

Palabras Claves: Colombia, competitiveness, software industry.

\footnotetext{
* Ingeniero de Sistemas de la Universidad Antonio Nariño, Especialista Ingeniería de Procesos y gestión de la Calidad Universidad EAN, Especialista en Gerencia de Proyectos - Colegio Mayor de Nuestra Señora del Rosario, Magister en Gestión de Organizaciones de la Universidad de Quebec y Doctor: Universidad Popular Autónoma del Estado de Puebla. Docente investigador de la Universidad EAN, Bogotá D.C. Colombia. Contacto: nmoreno@universidadean.edu.co :
}

Ingeniero de Diseño de la Universidad de la Salle, Especialista Administración de Empresas / Universidad EAN Gerencia de Proyectos en Ingeniería / Universidad de la Salle, Master en Administración de Empresas / Universidad Politécnica de Madrid, Doctorado en Dirección de Proyectos / Universidad Pública de Navarra (España). Director del Departamento de Proyectos, Directo del Grupo de Investigación Gestión de Proyectos, en la Universidad EAN, Bogotá D.C. Colombia. Contacto: hmdiez@universidadean.edu.co 


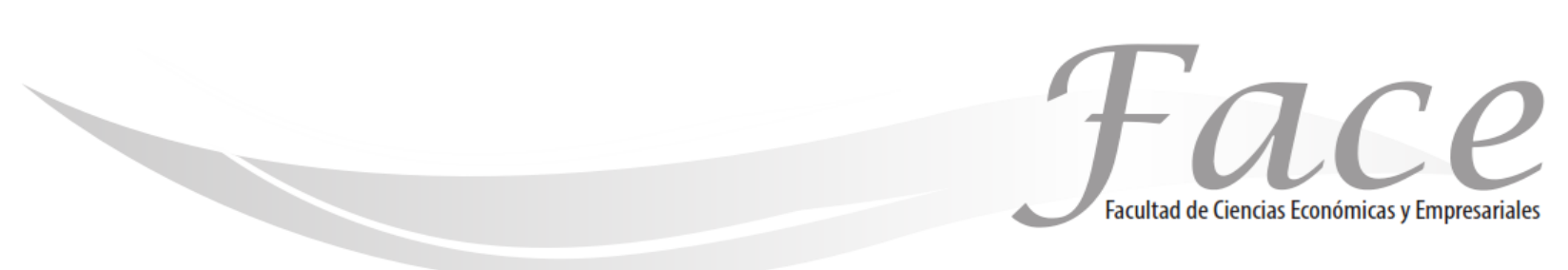

\title{
ANALISIS DE LOS FACTORES CLAVES PARA LA COMPETITIVIDAD EN LA INDUSTRIA DE SOFTWARE: PERSPECTIVA DE LOS NEGOCIOS EN COLOMBIA
}

\begin{abstract}
Resumen:
En este trabajo se presenta un análisis de los factores clave, que, desde el punto de vista de los empresarios de la industria de desarrollo de software de Colombia, pueden incidir de forma positiva en la competitividad de dicho sector. El punto de partida del proyecto de investigación se basa en las oportunidades de mejora que pueden generarse para este tipo de compañías, teniendo en cuenta que es una industria atractiva por su alto grado de innovación y el valor agregado de sus productos.

Para conseguir los propósitos de investigación se utilizó una estrategia de tipo mixta, con alcance exploratorio y descriptivo. Se desarrolló un trabajo interpretativo sobre fuentes bibliográficas de informes de carácter global y local, y posteriormente se diseñó un instrumento que permitiera obtener datos relacionados con los factores que pueden influir en la competitividad del sector descrito. A partir de la información recolectada se realiza un análisis de correlación de variables, estableciendo relaciones preliminares interesantes para efectos de intervención sectorial.

Se ha encontrado una correspondencia entre la competitividad y las variables asociadas con el apoyo gubernamental, calidad de la educación, certificaciones existentes, y procesos de apertura económica, los cuales son denominados en este caso, como los factores clave para la competitividad. Se pretende que los resultados documentados sean útiles, de cara a promover programas, planes, y proyectos sectoriales, para la mejora continua de las empresas que hacen parte del sector estudiado.
\end{abstract}

Keywords: Colombia, Competitividad, Industria del Software

\section{ANÁLISE DO EFEITO DA TAXA DE RETRIBUIÇÃO POR CONTAMINAÇÃO HÍDRICA NA COLÔMBIA}

\section{Resumo:}

Este trabalho apresenta uma análise dos fatores-chave que, visto a partir do ponto de vista dos empresários na indústria de desenvolvimento de software na Colômbia, pode ter um efeito positivo sobre a competitividade deste sector. 0 ponto de partida desta pesquisa é baseada em oportunidades de melhoria para essas empresas, tendo em conta o aspecto atrativo desta indústria devido ao seu alto grau de inovação e produtos de valor agregado.

A pesquisa foi desenvolvida com uma abordagem mista, com uma exploratória e um alcance descritivo; realizando uma obra interpretativa sobre fontes bibliográficas e, posteriormente, a concepção de um instrumento para a aquisição de dados relacionados com os fatores que influenciam a competitividade do sector. A partir destes resultados, uma análise de correlação de variáveis, útil para fins de intervenção sectorial foi realizada.

Como resultado, existe uma correlação entre competitividade e as variáveis associadas com o apoio do governo, a qualidade da educação, certificações e processos de abertura econômica existentes. Estes resultados são esperados para ser útil na promoção de programas, planos e projectos sectoriais para a melhoria contínua das empresas que fazem parte do setor analisado.

Palavras-Chave: Colômbia, a competitividade, a indústria de software. 


\section{INTRODUCCIÓN:}

The software industry in many countries and for decades now, has experienced an internal transformation, mainly due to the accelerated increase in its participation as a sustainable economic activity, and its contribution to improving production conditions in all other economic sectors. It is worth considering the situation that in several countries, this industry has a very important appreciative value, primarily owing to the possibility of manufacturing products with a high added value in knowledge, in turn contributing to the overall growth of the economy, both in local and global terms (PWC, 2010).

In that sense, there are many factors that may have influenced, and currently influence in the establishment of a system that can allow the software industry to improve its performance conditions, or at least maintain adequate levels, also contributing to the national economy activity to which it belongs. It is no secret that the software market is a source of innovation, which also guarantees a source of solving structural problems, an example of this is that some countries with emerging economies that have entered the software industry, nowadays are considered worldwide points of reference such as India, Ireland and Israel, or the 3 I's (Arora, 2005), recognized for high quality and product differentiation (PWC, 2010).

The development of this sector in India is a factor that has been stimulated on account of the creation of several technology parks that support exporting companies, boosting the software development industry. In turn, as it will be shown in the following sections, like Ireland and Israel, India placed its bet on education and the training of software engineers, creating programs and specialized institutions, and signing agreements with leading universities of world order (The European Software Institute - ESI, 2009). This has allowed India, for example, to become the country with the largest number of companies certified in Capabilty Maturity Model (CMMI), ensuring process quality in the products they develop.

In the same line, the software industry in Ireland represents $10 \%$ of GDP, generating employment for about 24,000 people, and profits close to 17,000 million euros. All these results can be seen, in part, because of the implementation of a marketing strategy focused on meeting external demand, primarily as a software provider in Europe (Ryan, 2009). On the other hand, public policies have also boosted the Irish software industry by increasing the educational provision, including universities with high level of R\&D (Steinbockova, 2007); and yet, according to the government, the sector's growth has been higher in relation to the number of graduates, requiring skilled labor to be imported (World Economic Forum, 2013).
In the particular case of Israel, one can observe a significant increase in software exports, with about 3500 million dollars a year, going from an economy that was based on citrus and cotton farming, to one that is oriented to the high technology sector. This can be evidenced in the concentration of computer companies, superseded only by the Silicon Valley in the United States (Perez, 2011). State support in Israel can be considered a key element to strengthen the software development field, with fiscal policies for soft loans, favoring the creation of new businesses and boosting research centers (Perez, 2011), as well as the quality of education, and trade agreements that have been signed with other countries.

If reference from other geographical contexts is made, it can be said that the comprehensive development of the Chinese economy has allowed the local market to open spaces for companies developing domestic and foreign software. For example, nowadays $33 \%$ of the domestic market is served by Chinese companies (Arora, 2005), the United States ranks first in software sales worldwide, and the demand for software for mobile devices has increased significantly (PWC, 2010). In that sense, it should be considered that changes in the economic sectors have generated a growth in the software industry with wider supply of enterprise software, or the purchase of small development companies by large multinationals.

In the case of America, it is no secret that United States ranks first position with companies like Microsoft, IBM and Oracle (Arora, 2005). In Latin America, Mexico, Argentina and Brazil stand out and take the first three positions, showing a fairly advanced degree of maturity and having many of their companies export their products, consolidating in this way their international presence (The European Software Institute - ESI, 2009). The leader in South America is Brazil, where the computer industry began as a result of policies that were implemented in the late seventies, and later in the nineties, economic openness made it necessary to implement development programs for ICT, stimulating industry (Stefanuto, 2007).

One of the competitiveness factors of the Brazilian software industry is the identification of this area as a strategic sector and the state support programs (Stefanuto, 2007). As weaknesses, this industry faces the division of the sector, lack of competitiveness in specific market niches, and low CMMI certification (ECLAC, 2009). Finally, another country that is at the forefront in this area is Chile, partly because it is one of the countries that has invested the most resources in education (Schwartzman, 2009), creating programs to secure the sustained growth of its software industry, and public policies to achieve global standards. Chile seeks to project itself in order to be recognized as a global platform 
for software solutions development, since it has seen in this industry an alternative to strengthen its economy.

The objective of this research focuses on the identification of the variables that may impact the competitiveness of the Colombian software development industry, which for illustrative purposes are called "key factors". For that, this paper starts with a review of the various reports published internationally, from which a measurement tool is designed, including competitiveness variables which greatest representativeness was observed in the literature. From the employer's perspective, the correlation degree of the identified variables is determined, thereby seeking to establish an order of priority and influence so they can be taken as a reference to promote an intervention exercise of this industry in Colombia.

\section{METODOLOGY:}

This research work has been developed under a mixed strategy, with a descriptive and an exploratory scope. The first part developes an interpretative work on bibliographic sources reporting global and local studies, qualitatively determining the factors that may affect the competitiveness of the sector under study. Subsequently and from the interpretation, a tool to evaluate the key factors selected by some of the employers in that industry in Colombia is designed. From the information gathered, a variables correlation analysis is performed, seeking to establish the relationships that can determine and prioritize the key competitiveness factors that were taken as a reference in the study, and the following hypotheses:

$\mathrm{H} 1$ : Government support is a key factor to increase the competitiveness in countries. The greater government support, increased competitiveness.

$\mathrm{H} 2$ : The quality of education directly impacts the competitiveness of countries. The higher quality of education, higher competitiveness.

H3: The adoption of better practices increase the competitiveness of countries. The greater adoption, increased competitiveness.

H4: Trade openness enhances the competitiveness of countries. The greater openness, increased competitiveness.

In order to carry out the assessment that is proposed for the Colombian context, and in accordance with the variables that were identified, a measurement tool consisting of 22 questions was structured, aregrouped into four different factors: [1] government support, [2] quality of education, [3] CMMI level certification, and [4] economic openness. The internal composition of the instrument is developed using a Likert-type scale for responses, where the absence or ineffectiveness of the factor is scored 1, and the strength or efficiency is scored 5 .

The structure of questions was seeking to identify the variables with the greatest impact on the Colombian software industry competitiveness, therefore, its composition was established from the four factors that were set out in the previous qualitative work, as follows: government support: 5 questions; quality of education: 6 questions; CMMI certification level: 6 questions; economic openness: 5 questions. A convenience sampling was used in Colombian software developing companies, which due to their size, seniority in the market and experience, gathered the necessary information to provide consistent characteristics. Finally, from the information obtained, the results are analyzed by applying a statistical model of lineal regression, identifying the relationship between variables.

\section{OVERALL PICTURE OD THE SORTWRE INDUSTRY IN COLOMBIA:}

The Colombian software industry is one of the most attractive enterprises in the country, mainly due to the great potential that can be seen in its companies. A point in favor of the Colombian case is its exponential rise, highlighting the quality of their products and the perseverance of entrepreneurs. In this context, to mention an important milestone, the Colombian government has designed different policies directed to largely meet the domestic demand for software, and also to capture overseas markets (The European Software Institute - ESI, 2009).

In terms of size, according to FEDESOFT (2009), by the year 2008 there were a total of 679 software developing companies in Colombia, out of which $97 \%$ were national and $3 \%$ foreign. Moreover, large, medium and small enterprises are concentrated in the larger capital cities in Colombia, such as Bogotá (62\%), Medellin (16\%), Cali $(9 \%)$, Bucaramanga $(5 \%)$ and Barranquilla $(4 \%)$, which are also the most important cities in the country, and therefore the ones with the largest population and potential demand. The previous point can be emphasized, by watching how, according to the ECLAC (Challenges and opportunities for the software industry in Latin America., 2009) the software industry of the country is dominated by micro and small enterprises engagement. 
With regard to the development in the sector, between 2000 and 2004, Colombia recorded a 48\% growth in the software market. As a precedent, in 2011 , less than $10 \%$ of the software developing companies had managed to successfully bring their products to other countries, phenomenon that has not allowed the positioning of the country brand in the industry, and therefore Colombian businessmen are being recognized as good "software artisans" (Economic and Commercial Office of the Embassy of Spain in Bogotá, 2006).

From the point of view of the type of product in the industry, Colombian companies have concentrated on the development of the custom software, that is, adjusting the product to the specific needs of each customer. Therefore, the local industry has not been able to make inroads in the development of packaged software, since this market is being served by multinationals from the United States and Europe, creating a market that is too competitive and has multiple barriers to entry (Castellanos, 2007).

Notwithstanding the possibilities and expectations, there are also weak points in the sector, such as the low standardization of development processes, high production costs and low brand positioning, which places the country in a less favorable position compared to its competition (Datanalisis, 2005). Among other disadvantages, drawbacks on the level of training and skill development, low level of bilingualism, low degree of certification in programming languages, and little investment to develop employees' innovative capabilities can also be referenced. All this, plus the decrease in the number of software engineering graduates, which has considerably reduced the skilled labor that is required to enhance the industry (ECLAC, 2009).
Consequently, the primary motivations for this research, are closely related to the challenges that are assossiated with the growing software market, as innovative export, own development, and quality; which would definitely require competitive actions in the international field, by observing practices that have been implemented by leading countries in this industry. In this regard, for example, it is necessary to increase the number of companies that are certified in the quality of their products as a distinctive element, against which Colombia has a lagged rate of only five companies with the highest degree of CMMI quality certification (FEDESOFT, 2009).

\section{RESULTS AND DISCUSSION:}

In this section the results of the study are analyzed, discussing their characteristics and possible implications for the development of the software industry sector. Concerning the first variable, related to the level of certification, specifically CMMI, we can infer that managers have the perception of high value-added in incorporating best practices from obtaining a high level of CMMI certification, and at the same time, they establish that a larger number of certified companies can contribute to increase the software industry competitiveness. In aspects linked to the software market, entrepreneurs believe that the customer prefers certified companies, valuing international certifications and good practices, further recognizing the complexity surrounding their achievement (Figure 1).

Figure 1. Average assessment results - CMMI certification level.

\begin{tabular}{llllll}
\hline \multicolumn{1}{c}{ QUESTION } & AVERAGE & & & \\
\hline
\end{tabular}

Source. Prepared by the authors based on the results of the research. 
ISSN: 1794-9920 Enero - Julio 2016

Another variable that is considered in this study is the quality of education in the countries. It can be said that the industry, and specifically their employers perceive the need to train professionals in the areas of software engineering, with quality graduates (Figure 2).
For the Colombian entrepreneur the education can generate profit in the development of competitive industries, much more if the processes in the current economic openness are observed, with the inclusión of foreign companies, generation of clusters, wherewith Colombian companies must rethink their strategy, improving quality and value contribution (Lopez, 2006).

Figure 2. Average assessment results - education quality.

\begin{tabular}{|c|c|c|c|c|c|c|c|c|}
\hline QUESTION & AVERAGE & \multicolumn{7}{|c|}{ GRAPHIC } \\
\hline $\begin{array}{l}\text { 8. Educational institutions in Colombia, aim their } \\
\text { efforts at quality assurance in their teaching }\end{array}$ & 3,27 & & & & & & & \\
\hline $\begin{array}{l}\text { 9. The yearly number of professional graduates } \\
\text { in software engineering is sufficient to meet the } \\
\text { needs of the country }\end{array}$ & 3,64 & $4, \infty$ & 3,27 & & 3,09 & 3,36 & & 3,82 \\
\hline $\begin{array}{l}\text { 10. The quality of professional graduates in } \\
\text { software engineering is excellent to meet the } \\
\text { country's needs }\end{array}$ & 3,09 & $\begin{array}{l}2, \infty \\
1, \infty\end{array}$ & & & & & & \\
\hline $\begin{array}{l}\text { 11. The curricula of professional software } \\
\text { engineering programs are frequently updated }\end{array}$ & 3,36 & $0, \infty 0$ & P8 & P9 & P10 & P11 & $\mathrm{P} 12$ & $\mathrm{P} 13$ \\
\hline $\begin{array}{l}\text { 12. Having people trained in software } \\
\text { development, increases the competitiveness of } \\
\text { the Colombian industry }\end{array}$ & 4,64 & & & & & & & \\
\hline $\begin{array}{l}\text { 13. The main problem limiting competitiveness } \\
\text { growth in Colombia is the low quality of } \\
\text { education }\end{array}$ & 3,82 & & & & & & & \\
\hline
\end{tabular}

Source. Prepared by the authors based on the results of the research.

Figure 3. Average assessment results - economic openness.

For the variable related to economic openness processes, it appears that employers do not see a threat in the arrival of foreign companies, on the contrary, with increased competition; the quality of the product has been improved. However, it can be seen that Colombian companies prefer to use foreign software rather than software that has been developed in the country. Figure 3 shows the results with the average value of the items corresponding to the mentioned variable.

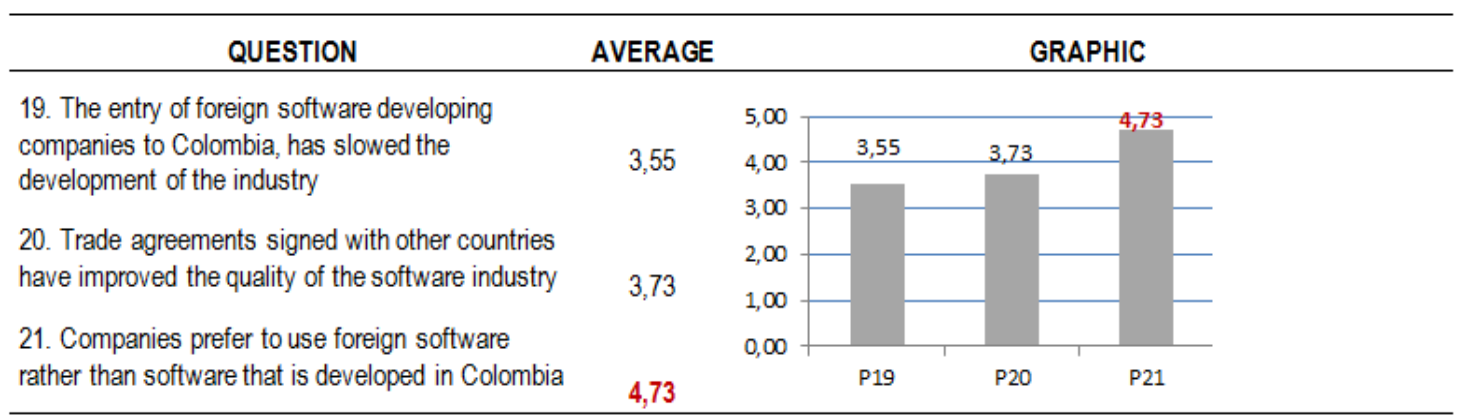

Rating scale: [1] Never, [2] Sometimes, [3] Frequently, [4] Almost always, [5] Always.

Source. Prepared by the authors based on the results of the research. 
In relation to the variable named organizational support, aimed at establishing the perception of entrepreneurs on the influence of government support in the competitiveness of the sector, the study reveals that businesspeople believe that with ongoing support they could compete in the Latin American software industry. Likewise, the need to increase investment in order to improve the quality of human capital in the industry is observed. Figure 4 presents the average results obtained in the evaluation of this variable.

Figure 4. Average assessment results - organizational
Supplementing the analysis above, from the application of a statistical regression model, an attempt to identify the relationship between the independent and dependent variables was made. An R-squared: 0.914 enables inference that the people surveyed perceive that the degree of competitiveness of the software industry in Colombia is associated with the support provided by the government, the quality of education in the country, the level of CMMI certification, and the entry of foreign companies into the country, generated by the process of economic openness. This conclusion can be validated with the result obtained in the critical value $F$ : 0.0023 , which shows that the dependent variable is explained largely by the independent variables (see Table 1 and 2).

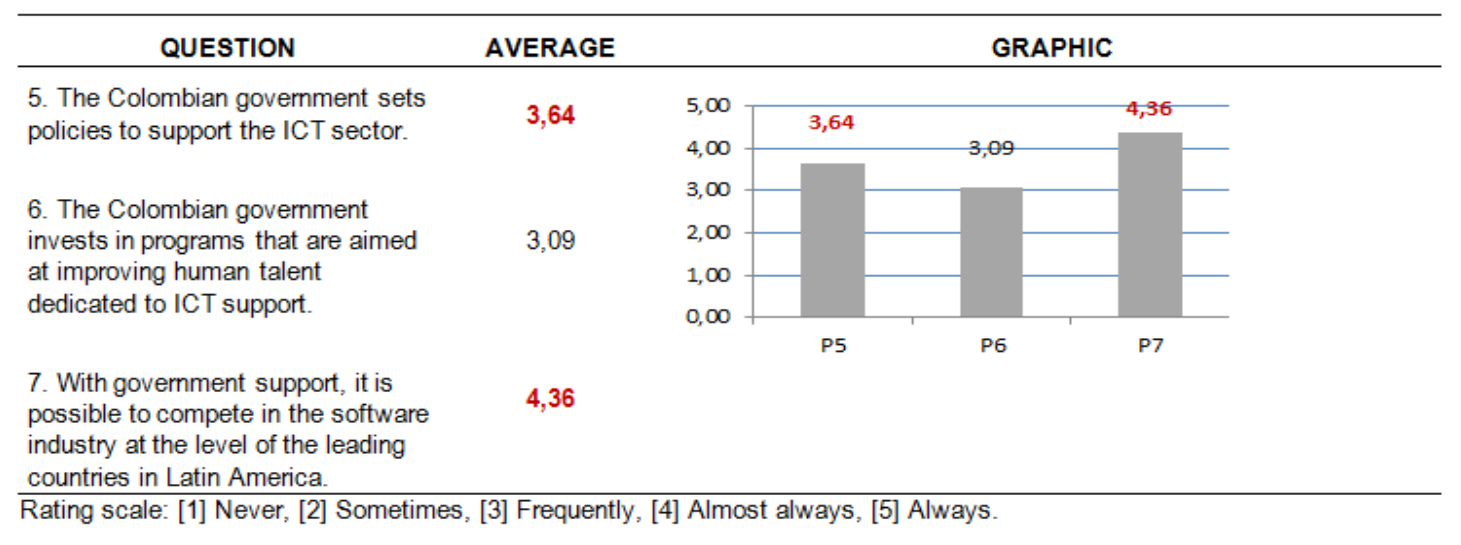

Source. Prepared by the authors based on the results of the research.

Supplementing the analysis above, from the application of a statistical regression model, an attempt to identify the relationship between the independent and dependent variables was made. An R-squared: 0.914 enables inference that the people surveyed perceive that the degree of competitiveness of the software industry in Colombia is associated with the support provided by the government, the quality of education in the country, the level of CMMI certification, and the entry of foreign companies into the country, generated by the process of economic openness. This conclusion can be validated with the result obtained in the critical value $F: 0.0023$, which shows that the dependent variable is explained largely by the independent variables (see Table 1 and 2).
Table 1. Regression results.

\begin{tabular}{lr}
\hline Regression statistics & \\
\hline $\begin{array}{l}\text { Correlation coefficient } \\
\text { multiple }\end{array}$ & 0,956098797 \\
Determination & \\
coefficient $\mathbf{R}^{\wedge} \mathbf{2}$ & $\mathbf{0 , 9 1 4 1 2 4 9 0 9}$ \\
Adapted $\mathrm{R}^{\wedge}$ & 0,856874849 \\
Standard error & 0,297451452 \\
Observations & 11 \\
\hline
\end{tabular}

Source. Prepared by the authors based on the results of the research.

The first instance shows a relationship between the level of CMMI certification and the improvement of competitiveness of the software industry in Colombia. This is consistent, due to the fact that if a company achieves a high level of certification, this guarantees the implementation of the best global practices in the market, and peace of mind for its customers. Nowadays, the global software industry favors companies with high levels of certification (UNCTAD, 2012). 
Table 2. Analysis of variance.support.

\begin{tabular}{ccc}
\hline & $\begin{array}{c}\text { Degrees of } \\
\text { freedom }\end{array}$ & Critical value of $\mathrm{F}$ \\
\hline Regression & $\mathbf{4}$ & $\mathbf{0 , 0 0 2 3 7 0 0 0 3}$ \\
Residues & 6 & \\
Total & 10 & \\
\hline
\end{tabular}

Source. Prepared by the authors based on the results of the research.

On the other hand, an estimate of the degree of correlation between the dependent (competitiveness) and the independent variables was performed, obtaining results that enable a prioritization of these variables, according to which the higher correlation variable on competitiveness is related to the levels of certification and standardization with international practice, as it can be seen in Table 3.

Table 3. Variables correlation.

\begin{tabular}{lr}
\hline & Competitivity \\
\hline Competitivity & 1 \\
Government & 0,617647059 \\
Education & 0,723339349 \\
Certification & 0,906492521 \\
Openness & 0,648338752 \\
\hline
\end{tabular}

Source. Prepared by the authors based on the results of the research.

Also, when analyzing the variable of quality of education, there is an index of correlation that is lower than the certification variable, with a high degree of significance: 0.723. In the case of the variables of government support and economic openness, although their results are similar and lower than the other two variables, one can infer that respondents found a degree of importance to improve competitiveness. Based on the above, a relationship between the variables of economic openness and competitiveness is found, and although the correlation degree is not high, it justifies that the signing of trade agreements impacts the Colombian software industry.

On the basis of the issues raised, the correspondence of variables that was performed is consistent, taking into account that the Presidency of the Republic of Colombia is making efforts to boost its economy by means of signing trade agreements with different countries, designing an action plan supported by three pillars: the economy internationalization, the productive transformation plan and Colombia as a tourist destination. It becomes clear then, the unlimited support on the part of the presidency to improve the country's competitiveness (Ministry of Commerce, Industry and Tourism, 2013), which is consistent with the results that were found during the development of this research.

\section{CONCLUSIONS:}

In this paper, we have analyzed the key factors, that seen from the point of view of entrepreneurs in the software development industry in Colombia, may have a positive effect on the competitiveness in this sector. From the results, it is posible to see the close relationship that there is between competitiveness, as the dependent variable, and government support, the quality of education, level of $\mathrm{CMMl}$, and economic openness, as independent variables. This allows us to validate the four hypotheses in this research:

H1: The greater government support, increased competitiveness. As evidenced in the models developed by countries such as Israel, India, Chile and Brazil, leaders of the worldwide software industry, it is from the generation of government policies that encourage entrepreneurship and the design of innovation and knowledge management plans, that they have managed to strengthen their industry, achieving significant growth and profitability figures. In Colombia, the government has been focused on trengthening the software industry, therefore, it has ccluded public policies to improve competitiveness.

$\mathrm{H} 2$ : The higher quality of education, higher competitiveness Undoubtedly, the main reference that validates this hypothesis is the Chilean case. This country has today one of the best educational levels in Latin America, thanks to the efforts undertaken from the decade of the 1970s. This country wants to project itself as a leader in the software market, creating an attractive image and strengthening existing businesses. As the Chilean case, we can mention cases like India and Brazil, who see in education one of the main factors to improve competitiveness and strengthen their economies. In Colombia, despite the awareness of the need to strengthen the educational models, it is still moving slowly. Today people prefer to attend humanistic programs rather than programs in the technical line, which has affected the Engineering carrers in the country. Also, compared to other countries, efforts should be made to ensure access to education and international visibility, to technical and technological programs, as well as to favor 
English as a second language, making the globalization process much simpler.

H3: The greater adoption of better practices, increased competitiveness. In this sense, Latin America is still in its incipient stage compared to countries like Ireland and India. The software industry recognises in the CMMI certification one of the standards that guarantees the quality of the products that are developed. Unfortunately, the number of certified companies in Latin America is low. The country with the largest number of certifications is Brazil, with basic level 1 , which is not an encouraging picture, considering that the highest level is 5. Ireland, Israel, India and the US have made great strides in this area forming the leading group in the international market. In addition, Colombian businessmen are aware of the need to obtain the different CMMI certification levels, but the difficulty in accessing the certification processes, the complexity of implementing the model and the high costs that must be assumed, discourage people to undertake a project of this nature.

H4: The greater openness, increased competitiveness. Ireland has opened the doors to foreign technology companies willing to operate in their country, this has allowed the country to be recognized as the Silicon Valley of Europe. Undoubtedly, the process of economic openness bring many advantages for the economies. Knowledge transfer processes, incorporation of better practices, the strengthening of the economy, the improvement in product quality and the internationalization of enterprises, are among others, the benefits that can be obtained (India, China, the US and Israel).

The Colombian case is no different. The country has not developed flagship products that can compete internationally, on the contrary, it has been devoted to the development of custom software, to the extent that the industry is recognized as an artisan software. Colombia, as well as its neighboring countries, is focused on serving the domestic market, since there are no options to compete in the international market. For the Colombian software industry to improve its competitiveness, it must focus its efforts on enhancing the variables that are highlighted and documented in this research.

For all the above, for purposes of argument presented, Colombia must maximize its commitment to software development, providing greater relevance to the policies of the country strategy, in order to improve the competitiveness of the industry, from brand positioning and the quality of the processes. Required processes of reflection, government, unions and business, to consider that software development involves a complex process of knowledge management, business creation and sectoral strategies backed by long range.
Given the above, for the purposes of the argument put forward, Colombia must maximize its commitment to software development, giving more relevance to the policies of the country strategy, aimed at improving the competitiveness of the industry, from the brand positioning and the quality of the processes. Processes of reflection in the government, unions and business are required to believe that software development involves a complex process of knowledge management, and entrerprice creation supported by long range sectoral strategies.

\section{REFERENCES:}

Arora, A. a. (2005). From Underdogs to Tigers: The Rise and Growth. NY, USA: Oxford University Press.

Avalos, I. (2003). Technology Transfer. Caracas: Nueva Sociedad.

Business Software Alliance (2011). IT Industry Competitiveness Index. Prepared by BSA Worldwide Headquarters, Washington, DC.

Castellanos, M. (2007). Industrial technology foresight study for the software industry and related services. Technical report, National University of Colombia. Bogotá D.C., Colombia.

CEPAL. (2009). Challenges and opportunities of the software industry in Latin America. Colombia: CEPAL and Mayol Ediciones S.A.

DANE. (2008). Measuring ICT in Colombia. Bogotá D.C., Colombia.

Datanalisis. (2005). Study of the software industry in Colombia 2005. Bogotá D.C., Colombia: Unpublished.

FEDESOFT. (2006). Importance of the software industry worldwide. Bogotá, D.C, Colombia.

FEDESOFT. (2009). The IT sector in colombia. Technical report. Bogotá D.C., Colombia.

Consultative, Scientific and Technological Forum (2009). Measuring the progress of societies: reflections from Mexico, pp 199-203. Prepared by the 
scientific and technological advisory forum, A.C., México Distrito Federal.

World Economic Forum. (15 March, 2013). Annual competitiveness report 2012 - 2013. Retrieven on 11 July, 2013, from:

http://reports.weforum.org/globalcompetitiveness-report-2012-2013/\#=

Santoro, M., Bierly, P., Gopalakrishnan, S. (2007). Organizational Learning from External Sources: New Issues and implications. International Journal of Technology Management, 38 (1/2), p. 6-19.

López, F. (2006). Competitiveness in Colombia: Economic openness, support institutions and democratic security. EAFIT University Magazine . 42 (142), 9-25.

Ministry of Science and Technology of Brazil. (2004). Innovation Law 10973. Sao Pablo, Brasil.

Mon Alicia, e. a. (2009). Improvement in processes for software SMEs. Buenos Aires, Argentina.: Buenos Aires University.

Noriega, M. S. (2006). Technological transfer: ¿what can we learn from international experience? Journal of Technological Management \& Innovation, 1 (3), 1-3.

Economic and commercial office of the Spanish Embassy in Bogotá. (2005). The software market in Colombia. Bogotá D.C., Colombia.

Economic and commercial office of the Spanish Embassy in Bogotá. (2006). Sectoral notes: the software market in Colombia. Bogotá D.C., Colombia.

Perez, A. L. (2011). Growth of companies with late-entry into the standardized software market: an approach from the multigenerational competitive difussion modelling, with network effects. Doctoral thesis, National University of Medellín, Mines Faculty, Computer Systems School, Systems and Informatics Engineering. Medellín, Colombia.

PWC. (2010). Global 100 Software Leaders. NY, USA.
Stefanuto, G. (2007). A Indústria de Software no Brasil: fortalecendo a Economia do Conhecimento. Secretaria de Ciência e Tecnologia doEstado do Paraná (FINEP). (4), 37-48.

The European Software Institute - ESI. (2009). Software Industry in Colombia - Technical report, European Software. Madrid. Spain: Institute- Tecnalia.

Vaccarezza, L. (2011). Science, Technology and Society: the state of affairs in Latin America. Madrid: McGraw Hill.

World Economic Forum. (2013). Global Competitiveness Report 2013-2014. The Global Competitiveness Index 2013-2014: Innovation and sophistication factors. NY, USA.

Yutronic, J. (2010). Science, technology and innovation in Chile into the 21st century. Subjects in Latin America. Globalization, Science and Technology, (3), 115 - 142. 